\title{
Military Parachute History of Hungary
}

\author{
József BODA ${ }^{1}$
}

\begin{abstract}
The author shall summarize the history of Hungarian military parachuting and share it with those interested in the topic. The article begins with the Imperial and Royal Aviation Troops of the Austro-Hungarian Empire parachute activities followed by the history of the participation in World War II and during the Warsaw Pact era until recent years.

In Hungary, so far, only a few books have been published covering the history and activities of parachute and special forces units.
\end{abstract}

Keywords: long-range reconnaissance, military parachuting, parachute, paratroopers special forces

\section{Introduction}

During the first years of the 1914-1918 war, the parachute was largely unknown among the Hungarian and Austrian military aviation troops. The use of parachutes started in 1917 within the units of captive (observation) balloons; at the end of the war it was increasingly used by combat pilots and crew members.

Until the end of the war, all in all, 177 jumps occurred, nearly all of them out of a captive balloon, only 8 jumps were counted out of airplanes.

54 jumps out of captive balloons were because of aviation attacks, 115 were made for training reasons. From planes 6 jumps were counted; all caused by aviation attacks, 2 due to plane crashes. 162 jumps out of the balloons happened without any complications, in 5 landings some persons were slightly, and 2 of them were fatally, injured. 2 jumps out of airplanes happened without any complication, in one of them a person was slightly injured and four fatally.

\section{The Beginning}

Lieutenant Theodor Spalek, equipped with a "Brunner" parachute made most of the drops all with smooth landings. He parachuted down from an altitude of between 300 and 700 meters twelve times. Lieutenant Leopold Gorke parachuted down from an altitude of between 90 and 400 meters six times, all jumps with smooth landings. [1: 276]

On $30^{\text {th }}$ November, 1917 Lieutenant Alfred Bibicas, a member of the $13^{\text {th }}$ Balloon Company, was killed while dropping out of his burning captive balloon because his parachute was damaged by the burning parts of the balloon.

On $23^{\text {rd }}$ March, 1918 Lieutenant Antal Boksay, a member of the $24^{\text {th }}$ Reconnaissance Aviation Company, tested the German Heinecke I. parachute by jumping from 2000 m. [2: 32]

1 Dr. (Ph.D.) habil., National University of Public Service, Law Enforcement Faculty; e-mail: boda.jozsef@ uni-nke.hu 
On $8^{\text {th }}$ May, 1918 Lieutenant Baron von Scholten, a member of the $20^{\text {th }}$ Balloon Company, was killed while parachuting, due to a defective parachute. On 22 ${ }^{\text {nd }}$ August, 1918 Lieutenant Frigyes Hefty, $42^{\text {nd }}$ Aviation Company parachuted from an altitude of 4,800 $\mathrm{m}$ after his plane was hit in an air fight and caught fire. On $6^{\text {th }}$ September, 1918 Corporal Karl Thomas, 30 $0^{\text {th }}$ Aviation Company, jumped from his plane after a wing was hit. Both Hefty and Thomas managed to land without injury.

On $28^{\text {th }}$ August, 1918 both Lieutenant August Selinger, a member of the $42^{\text {nd }}$ Aviation Company, and Staff Sergeant Konrad Kraus, were killed for reasons that were never clarified; Lance Corporal Ludwig Thaler, $14^{\text {th }}$ Aviation Company met the same fate on $18^{\text {th }}$ September, 1918 because, his parachute was interfered with, as did Lieutenant Franz Sedelmeier of $22^{\text {nd }}$ Aviation Company, on $12^{\text {th }}$ September, 1918 for reasons unknown.

In 1936, a parachute factory was established in Hungary.

On $12^{\text {th }}$ June, 1937 during the International Red Cross Rescue Conference in Budapest, a Medical Team with two nurses (Gabriella Medveczky and Margit Tatár) parachuted from an altitude of $800 \mathrm{~m}$. [3] They were the first female parachutists in Hungary.

On $3^{\text {rd }}$ May, 1938 the first military parachute training was organized for a special military detachment to carry out missions behind enemy lines.

In 1938, a Hungarian engineer, Ákos Hehs, created the first Hungarian parachute, called H 39 M. [4]

\section{Establishment of Parachute Units}

On $1^{\text {st }}$ October, 1939, the $1^{\text {st }}$ Parachute Battalion and in 1944, the $1^{\text {st }}$ Parachute Regiment were founded.

The unit had two parachute combat missions during World War II (WW II). Since WW II, the Hungarian parachutist units were the elite force of the Hungarian armed forces. These units were always used in difficult and dangerous situations when other units were not able to fight effectively. [5: 29-33]

After WW II, on $1^{\text {st }}$ October, 1948 the first parachute company was re-established and in 1950 the company became the $62^{\text {nd }}$ Parachute Battalion of the Hungarian Land Forces.

In 1949, the Parachute Service of the Hungarian Air Force was established.

On $30^{\text {th }}$ November, 1954 , the $62^{\text {nd }}$ Parachute Battalion came to an end.

The third generation of the Hungarian parachutists started in 1959, by establishing a longrange (LR) reconnaissance company, and in 1961, it became the $34^{\text {th }}$ Reconnaissance Battalion. Later on, in 2006, the unit became the $34^{\text {th }}$ Special Forces Battalion.

On $30^{\text {th }}$ July, 1957, a paramilitary organization (Hungarian National Defence Association) was established to conduct pre-military training for juveniles including parachute training.

Between 1960, and 1990, each of the five divisions of the Hungarian Land Forces had a Long-Range Reconnaissance Company. They had qualified military paratroopers.

In 1972, the Search and Rescue Service of the Hungarian Air Force with parachute capabilities was founded. 


\section{Changes after the Cold War}

Since 1989, when the political changes took place in Hungary, the armed forces have been undergoing constant reduction.

In 1993, the $88^{\text {th }}$ Air Mobile Battalion was established with parachute capability. In the year 2000, the battalion became the $1^{\text {st }}$ Light Mixed Infantry Regiment. In 2005, the regiment was downsized to battalion level, called 25/88 ${ }^{\text {th }}$ Light Mixed Infantry Battalion. [6: 128]

In 2004, there was a tendency to dismiss all special parachute units for financial and political reasons (joining the EU). With the assistance of Fellowship Association of Hungarian Parachutists (FAHP), the special parachute units survived the changes again, but the number of units and members of the units have been reduced.

By the end of 2008, there were three battalion size units and one Peace Support Training Centre with parachute capabilities and three air bases with parachute support staff and search and rescue capabilities. In $1^{\text {st }}$ January, 2016 by merging the $34^{\text {th }}$ Special Forces Battalion and 25/88 ${ }^{\text {th }}$ Light Mixed Infantry Battalion the $2^{\text {nd }}$ Special Forces Regiment was established. Altogether today there are 250 military parachutists in Hungary.

\section{The $2^{\text {nd }}$ Special Forces Regiment (2016-)}

The 1,200-strong $2^{\text {nd }}$ Special Forces Regiment was established in $1^{\text {st }}$ January, 2016.

The soldiers applying to join the unit must first undergo a very rigorous assessment and selection process. The future members of the regiment all want to be among the best, but due to the very heavy physical and mental strain, only 10-15 percent of the applicants are able to meet the requirements.

The Special Forces Regiment can be deployed "by land, by water, under water and by air”, both in Hungary and abroad. The Hungarian Special Forces enjoy international recognition, and, for example, they have led the special forces group of seven countries in Afghanistan for six months. [7]

\section{Missions}

The scope of the battalion's duties is defined by the Ministry of Defence in 229-50/2015. deed of foundation:

- execution of Special Operation missions under national and NATO command (Special Reconnaissance, Direct Actions, Military Assistance);

- contribution to Peacekeeping operations;

- participation in Peacetime or Combat Search and Rescue operations;

- conducting Military Operations to protect Hungary and its allies;

- organizing Task Force Groups and conduct special military operations in cooperation with Air Force and other Land Forces support units in case of emergency;

- conducting special tasks in case a traditional military unit is not capable of doing it;

- prepared to conduct military policing tasks. 


\section{Structure and organization}

The regiment was made up of combat, combat support and combat service support sub-units. Two combat battalions fulfil the regiment's main tasks. [8]

\section{The $34^{\text {th }}$ László Bercsényi Special Forces Battalion (1939-2015)}

\section{History}

The legal predecessor of the $34^{\text {th }}$ László Bercsényi Special Forces Battalion is the $1^{\text {st }}$ Parachute Battalion, which was founded on $1^{\text {st }}$ October, 1939 in Pápa. The second parachute unit was founded on $4^{\text {th }}$ October, 1951 in Székesfehérvár and carried forward the tradition of airborne infantry. The unit was deactivated in 1954, and reactivated and reorganized in 1959, in Budapest as a Long-Range Reconnaissance Battalion. During 1961, the unit was equipped with the new Russian made D-1 type parachute. Within the frame of restructuring the battalion, it was redeployed to Szolnok in 1963. The unit executed the first parachute jumps from MI-8 helicopter in 1973, and from AN-26 airplane in 1977.

The battalion was named after Count László Bercsényi in 1990. The unit took part in securing the Southern borders during the Balkan War. [9]

Since Hungary joined to the North Atlantic Treaty Organization (NATO) in 1999, the $1^{\text {st }}$ company of the battalion was assigned to the Allied Command Europe Mobile Force-Land (AMF-L). Between 2002-2003, with the reorganization of AMF-L, the company became a part of NATO Response Force (NRF) and carried out a mission in 2003, for six months' periods. Members of the battalion served in many peacekeeping missions like Cyprus - United Nations Peacekeeping Force in Cyprus (UNFICYP); Egypt - Multinational Force and Observers (MFO); Bosnia-Herzegovina - Stabilization Force (SFOR); Kosovo - Kosovo Force (KFOR); and Iraq - NATO Mission.

In 2004, one whole company was deployed to International Security Assistance Force (ISAF) mission in Afghanistan. The Reconnaissance Battalion completed its transformation to a Special Forces Battalion in 2006.

Some elements of the $34^{\text {th }}$ Recce Battalion deployed several times to conduct special missions. Between 2004 and 2006, the Battalion provided the majority of the Light Infantry Company in Kabul, Afghanistan. Additionally, teams deployed into Iraq, as training teams to train the Iraqi Security Forces. In 2008, the Battalion - together with the 25/88 ${ }^{\text {th }}$ Battalionprovided the $4^{\text {th }}$ contingent of the Hungarian Provincial Reconstruction Team (PRT) in Afghanistan. From 2009, again, together with the $25 / 88^{\text {th }}$ Battalion they formed the first rotation of the Hungarian Operational Mentoring and Liaison Team (OMLT) in Baghlan Province Afghanistan. Also in 2009, the Battalion deployed teams to conduct special operations under ISAF command.

\section{Missions}

The scope of the battalion's duties is defined by the Ministry of Defence in 158/2005 deed of foundation:

- solutions to unexpected events with the use of military force; 
- execution of special operation missions under national and NATO command;

- combating terrorism (military aspect);

- contribution to peacekeeping operations;

- participation in peacetime or combat search and rescue operations;

- crisis management.

\section{Structure and Organization}

The battalion was made of combat, combat support and combat service support sub-units. Two combat companies fulfil the battalion's main tasks. In connection with the special organization within the unit, they are able to carry out special operation missions with small units (12 men group) up to platoon level.

\section{Objective}

To deploy in the European Union and NATO peacekeeping missions, in accordance with the national interest of Hungary. [6: 126]

\section{The 25/88 ${ }^{\text {th }}$ Light Mixed Infantry Battalion (1993-2015)}

\section{History}

The $88^{\text {th }}$ Light Infantry Battalion was founded on $1^{\text {st }}$ September, 1993 as an Air Mobile Battalion. After three years, it was reorganized and started its operation as Rapid Reaction Battalion on $1^{\text {st }}$ March, 1996. Finally, within the frame of the reorganization of a new military force, the unit grew from a battalion to a regiment on $1^{\text {st }}$ October, 2000. By $1^{\text {st }}$ July, 2001 the unit achieved combat readiness. After that, the regiment was reorganized and on $1^{\text {st }}$ September, 2004 started its operation as a Light Infantry Battalion. The battalion was under direct command of the $25^{\text {th }}$ György Klapka Light Infantry Brigade.

\section{Missions}

The battalion was an armed tactical unit with armed and professional subunits in its organization. Its technical equipment was modified for air transportation and the soldiers are trained and prepared for implementing extraordinary tasks.

Within the range of battalion's tasks, are wartime missions as well as other military operations.

Missions in wartime:

- crisis management;

- special operations;

- special infantry tasks;

- airborne and air assault operation;

- combat search and rescue. 
Other military operations:

- peace support operations;

- humanitarian relief;

- search and rescue;

- non-combatant evacuation;

- counter-terrorist operations.

\section{Structure and Organization}

The structure of the battalion consisted of combat, combat support and combat service support subunits.

Within the combat support subunits there were:

- combat support company (recce platoon, airborne, engineers platoon, mortar platoon, anti-tank platoon);

- a headquarters (HQ) company.

The battalion also had a logistic company and a medical centre.

The combat subunits consisted of three air assault companies.

During the foundation of the structure, the principal intent of the military superior was to establish a light infantry unit, which can be deployed anytime, anywhere, under any circumstances. Its mission implementation is characterized by considerable independence. [6: 129-130]

\section{The 5/24 ${ }^{\text {th }}$ Gergely Bornemissza Reconnaissance Battalion (1949-2016)}

\section{History}

The $24^{\text {th }}$ Gergely Bornemissza Reconnaissance Battalion was one of the units in the Hungarian Defence Forces that conducted parachute training. It was established in Esztergomtábor in 1949. After being reorganized a lot, it was located at the István Dobó Barracks (Eger). The primary mission of the unit was to train reconnaissance soldiers able and capable of providing intelligence data at operational level. In 1962, a Long-Range Reconnaissance Platoon was established within the unit with the intention of extending the recce capabilities of the battalion. One year later this platoon was reorganized into a company composed of 6 LR teams which adopted parachutes as a way of deploying troops behind enemy lines. In 1963, the Long-Range Company started its training with volunteers selected from the enlisted. The training jumps have been conducted in different parts of the country, e.g. Balatonkiliti, Pér, Szombathely, Kaposújlak, Szolnok, Mezőkövesd, Verpelét, Kaposvár and Kecskemét. The aircrafts and helicopters that have been used by the battalion were: LI-2, IL-14, AN-2, AN-26, MI-2, MI-8, MI-17 and KA-26. [10: 140-161]

During the compulsory military service (1963-2004), approximately 1,600 para-soldiers were trained by the $24^{\text {th }}$ Recce Battalion. In 2004, compulsory military service ended and therefore that year there was a milestone as regards parachute training as well. The new professional soldiers (mostly recruited from former enlisted and trained ones) meet the increased requirements; more than $80 \%$ of them have already completed the free fall course. From 1962 
through to 2008, the soldiers of the unit conducted approximately 50,000 jumps. [10: 183]

In 2007, the battalion was deployed to the city of Debrecen and became a subordinate battalion of the $5^{\text {th }}$ István Bocskai Infantry Brigade and was renamed to 5/24 $4^{\text {th }}$ Gergely Bornemissza Reconnaissance Battalion.

\section{Missions}

As a part of the Hungarian Defence Forces (HDF) Land Forces, the Battalion had to prepare the personnel for war operations, to ensure the readiness of combat and transport vehicles, as well as of the weaponry and technical equipment, to store and maintain material supplies, to prepare for mobilization in higher readiness state, to be capable of increasing unit size in a swift and organized fashion during mobilization, and to execute any warfare missions given to the organization.

\section{Structure and Organization}

- Headquarters;

- Support Subunits:

- Combat Support Company;

- Medical Centre.

- Combat Subunits:

- $1^{\text {st }}$ Reconnaissance Company;

- $2^{\text {nd }}$ Reconnaissance Company;

- $3^{\text {rd }}$ Reconnaissance Support Company.

\section{The Peace Support Training Centre (2000-2016)}

\section{History}

The Peace Support Training Centre (PSTC) was established on $1^{\text {st }}$ October, 2000 as part of the $1^{\text {st }}$ Light Infantry Regiment. The first task was to prepare military units for the missions of Cyprus - UNFICYP and Egypt - MFO. Later its tasks extended to NATO and EU missions as well. The PSTC is certified by the UN to organize International Military Observers Courses. By $1^{\text {st }}$ May, 2004 the PSTC became an independent unit attached to the Joint Operation Centre of the Hungarian Defence Forces.

In 2005, the PSTC was transferred to the Land Forces Command which was renamed Joint Force Command by 2007. The PSTC is also responsible for organizing training for special forces including parachute training. On April 2007, the United Nations Department of Peacekeeping Operations (UN DPKO) issued a certificate to recognize that the international military observer courses delivered by PSTC meet the UN peacekeeping training standards.

\section{Missions}

- To train military units and officers for peacekeeping missions.

- To prepare military observers for peace operations.

- To provide basic trainings for special forces units. 
- To organize conferences, seminars and military exercises on peace operations.

- To provide language trainings.

\section{Structure}

- Headquarters;

- Information Technology (IT) section;

- Operation section;

- Training section (including parachute trainers);

- Support section;

- Base/facility support section. [11]

Since the establishment of the $2^{\text {nd }}$ Special Forces Regiment, all the special training conducted by them and PSTC previously, are not provided any more.

\section{6 $^{\text {th }}$ Szolnok Helicopter Base}

The helicopter unit is based at an airfield with a considerable history in aviation, situated near the city of Szolnok and east of the Tisza river. Since the beginning of the 1940's the airfield has been used by military aircraft.

The $86^{\text {th }}$ Szolnok Helicopter Wing was established on $1^{\text {st }}$ August, 2004 from the $87^{\text {th }} \mathrm{Ba}$ kony Attack Helicopter Wing and the $89^{\text {th }}$ Szolnok Mixed Air Transport Wing. A reorganization took place in 2007, and the unit name changed again to $86^{\text {th }}$ Szolnok Helicopter Base. [12: 9]

\section{Main Tasks of the Base}

- Providing air transport and air fire support during national and international (military) crises situations and during combat for Hungarian military units and personnel.

- Air rescue and search service in Hungary.

- Providing internal and international military air transport.

- Conducting operational and practising aviation.

- Provide training for pilots and air technical staff conducting activities relating to NATO.

- Flight Training in Canada programme.

- Providing air support and protection for army units.

- Conducting standby duties - carry out tactical airborne operations.

- Operating the Military Parachute School for the Hungarian Defence Forces.

- Participation and assistance during national disasters and environmental catastrophes.

- Providing logistical support to other units in the garrison.

- Providing air transportation to national and military VIP’s.

- Preserve military aviation history and operate the Military Air History Museum in Szolnok. [12: 17] 


\section{Structure}

- Headquarters;

- Operation Centre of the Base;

- Transport Helicopter Battalion (MI-8 and MI-17);

- Attack Helicopter Battalion (MI-24D, MI-24V and MI-24P);

- Training Air Squadron (JAK-52, AS-350B light helicopter);

- Military Parachute School (company size);

- Aviation Engineer Battalion;

- Combat Service Support Battalion;

- Operations Support Battalion. [13]

\section{$59^{\text {th }}$ Dezső Szentgyörgyi Air Base Kecskemét}

The airfield has been operating since 1937. The predecessor regiment of the unit was established in 1951, and was equipped with MIG-15 and MIG-17 aircraft. In 1962, the regiment received some supersonic MIG-21, and in 1996, MIG-29 fighters. Since 2007, the air base has belonged to the Hungarian Defence Forces Joint Force Command (HDF JFC). In the same year, new Gripen fighter planes arrived to the unit.

\section{Organizational Mission}

Protecting the airspace, territory and troops of Hungary and its NATO allies, and securing its integrity in cooperation with the units and subunits of NATO and the Hungarian Air Force.

\section{Main Tasks}

- Continuous readiness in order to counter the activities of any aircraft that violates the airspace or the aviation regulations, as well as rescuing the crew of any troubled aircraft.

- Protecting Hungary and the member states of NATO and their troops against enemy air strikes.

- Visual air reconnaissance.

- Air support.

\section{Immediate Reaction Forces}

The purposes of this organization are:

- enforcing regulations on aircraft that violate the airspace or breaches the aviation regulations;

- provide air support to Hungarian and NATO Land Forces;

- carry out air reconnaissance;

- air transportation military personnel and units;

- rescuing the crew of any troubled aircraft by a platoon of parachutists. [14: 16] 
In 2001, the Swedish and Hungarian governments entered into a lease-purchase agreement, with a further modification in 2003, which included 14 Gripen C/D (12 single-seat plus two twin-seat) aircraft. All Gripens were delivered in 2006 and 2007, and, by the end of 2008, the 14 aircraft were in operational service in the Hungarian Air Force.

\section{Structure}

- Headquarters;

- Fighter Squadron (JAS-39 EBS HU GRIPEN);

- Air Transport Company (AN-26T);

- Air Tactical Training Squadron;

- Air Engineer Battalion;

- Combat Support Battalion;

- Base Operation Centre;

- Logistic Battalion including a Parachute Platoon.

\section{Pápa Base Airfield}

The Pápa Air Base was established on 1 1 July, 2001 as part of national commitments in the NATO Infrastructural Development Program, and it is the legal successor of the HDF $47^{\text {th }}$ Pápa Tactical Fighter Wing. It serves as a backup airfield for both Hungarian and NATO aircrafts and hosts Hungarian Air Force Search and Rescue helicopters. The Air Base was selected to be the Main Operating Base for the multinational Heavy Airlift Wing and its C-17 fleet in 2007. [15]

\section{Mission}

To host the NATO Strategic Airlift Command (SAC) and the Heavy Air Transport Regiment equipped with $\mathrm{C}-17$ aircrafts.

To provide Rescue Service for the Hungarian Armed Forces with a parachute platoon.

\section{Conclusions}

Since the dissolution of the Warsaw Pact in 1990, Hungary is constantly trying to modernise and downsize its armed forces. Having inherited a legacy of a heavy, slow-moving Warsaw Pact force, it is trying to modify it into a more versatile and modernised NATO force. The Hungarian military has been downsized from 130,000 in 1989, to approximately 24,000 in 2008. Furthermore, the Hungarian armed forces undergo a structural adaptation, which includes the formation of an army composed solely of volunteers, the establishment of mission orientated organisations, and, finally, the construction of a new service culture.

The main tasks now of the restructured parachute and special forces units are to participate in NATO and EU missions. 


\section{References}

[1] ERNST P.: Die K.u.K Luftschiffer- und Fliegertruppe Österreich-Ungarns. 1794-1919. Stuttgart: Motorbuch Verl., 1981.

[2] RÁTHONYI J.: Halálugrás Tirolban. Magyarország, 1984. 11. 07.

[3] VÁLLAY Gy.: Az első nemzetközi légi mentésügyi konferencia és bemutatók. Magyar Vöröskereszt, XXII 5-6 (1937), 12.

[4] HEHS Á.: A magyar ejtőernyő története. Magyar Szárnyak, X 16 (1981), 27-31.

[5] HUSZÁR J.: Honvéd ejtőernyősök Pápán 1939-1945. Pápa: Jókai Kör, 1993.

[6] KERESZTÚRI L., RUSZIN R.: A magyar katonai ejtőernyőzés története a rendszerváltástól napjainkig. In. BODA J., RUSZIN R. (szerk.), Levegőből harcba. A magyar katonai ejtőernyőzés története és változó feladatrendszere. na. Budapest: Zrínyi Kiadó, 2012.

[7] 61/2015. (XI. 4.) HM utasítás a Magyar Honvédség különleges müveleti képességének átalakításával kapcsolatos egyes feladatokról. www.kozlonyok.hu/kozlonyok/ Kozlonyok/12/PDF/2015/55.pdf (Downloaded: 2108 2016)

[8] MH 2. vitéz Bertalan Árpád Különleges Rendeltetésű Ezred. www.honvedelem.hu/szervezet/ mh_2_kulonleges_rendeltetesu_ezred (Downloaded: 2808 2016)

[9] SZABÓ F.: Az MN 34. Bercsényi László Önálló (Mélységi) Felderítő Zászlóalj története (1963-2005). In. Magyar Ejtőernyősök Bajtársi Szövetsége (szerk.), Legendák és titkok katonái. A mélységi felderítés története. 108-214. Budapest: Zrínyi Kiadó, 2012.

[10] SZABÓ J.: Az MN 4. Gépesített Lövészhadosztály 24. önálló felderítő-zászlóalj mélységi felderítőszázada. In. Magyar Ejtőernyősök Bajtársi Szövetsége (szerk.), Legendák és titkok katonái. A mélységi felderítés története. 140-161. Budapest: Zrínyi Kiadó, 2012.

[11] MH Béketámogató Kiképző Központ. (HDF Peace Support Training Centre.) www.pstc.hu/ rovatok/kozerdeku-adatok/ (Downloaded: 2108 2016)

[12] MAMÓCZ Gy. (szerk.): Roaring Dragons HDF 86 "Szolnok" Helicopter Base. Budapest: Zrínyi Kiadó, 2008.

[13] MH 86. Szolnok Helikopter Bázis. http://lhsn.hu/mh-86-szolnok-helikopter-bazis/ (Downloaded: 2108 2016)

[14] ZÁM K.: Air Patrol in Kecskemét. Budapest: Zrínyi Kiadó, 2007.

[15] NSPA: Vision, Mission and Values. Luxembourg: NATO Support and Procurement Agency, s.d. www.nspa.nato.int/en/organization/NAMP/mission.htm (Downloaded: 2108 2016) 